\title{
New dietary records for the Cuban Spotted Red Trope, Tropidophis macula- tus (Squamata: Tropidophiidae)
}

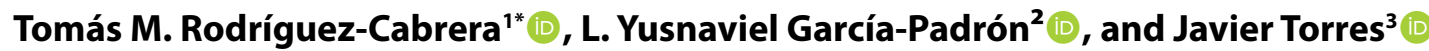 \\ 'Sociedad Cubana de Zoología, Cuba. \\ ${ }^{2}$ Museo de Historia Natural "Tranquilino Sandalio de Noda”. Martí 202, Pinar del Río, Cuba. \\ ${ }^{3}$ Department of Ecology and Evolutionary Biology, University of Kansas, Lawrence, Kansas 66045, USA. \\ *Corresponding author (tomasmichel.rodriguez@gmail.com)
}

Edited by: Robert W. Henderson. Date of publication: 14 May 2020.

Citation: Rodríguez-Cabrera TM, García-Padrón LY, and Torres J (2020) New dietary records for the Cuban Spotted Red Trope, Tropidophis maculatus (Squamata: Tropidophiidae). Caribbean Herpetology, 73, 1-2.

DOI: https://doi.org/10.31611/ch.73

Tropidophis maculatus (Bibron, 1840) is a mesophilic snake inhabiting forest patches and open secondary scrub savannas in western and central Cuba (Schwartz \& Henderson 1991; Rodríguez et al. 2013). The only dietary records for this species are the lizards Anolis angusticeps and A. alutaceus, for individuals from Havana city (Collette 1961). Herein we provide new data on the diet of wild T. maculatus.

On 17 April 2010, we found a juvenile female Tropidophis maculatus (140 mm SVL) at Soroa (22.7960, $-83.0060 ; 200 \mathrm{~m}$ a.s.l.), Candelaria Municipality, Artemisa Province. We found the snake at 1317 hours under a rock with a big stomach bulge (Fig. 1). It later regurgitated a partially digested male Anolis homolechis that had been swallowed head first (ca. $40 \mathrm{~mm}$ SVL; Fig. 2). The predominant vegetation in the area is semi-deciduous forest.

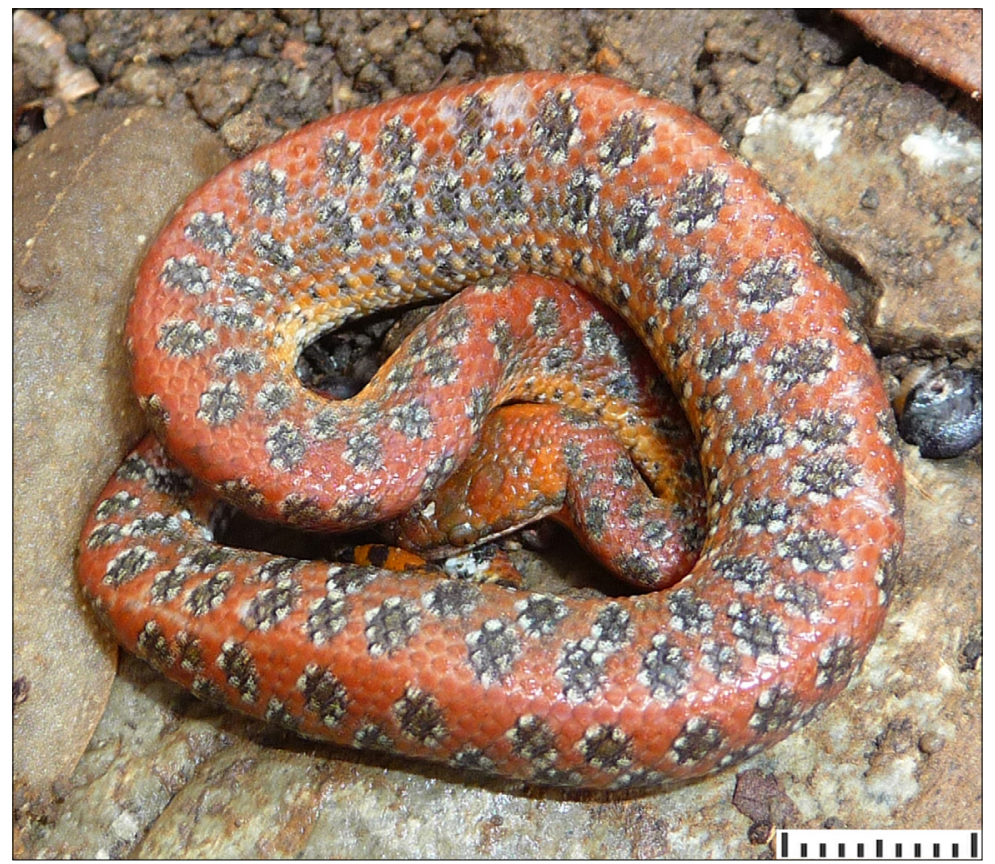

Figure 1. Juvenile female Spotted Red Trope (Tropidophis maculatus) with large stomach bulge, when first seen under a rock. Photo by Ruben Marrero.

On 2 October 2014, we encountered an adult T. maculatus (362 mm SVL) near "El Jagüey" (22.4224, -83.7242; 80 m a.s.l.), on the road to Luis Lazo, 2.5 km from Pinar del Río city, Pinar del Río Province. We found the snake at 0900 hours resting under a concrete block $(800 \times 350 \mathrm{~mm})$ in a suburban area. The stomach content revealed an indeterminate beetle of the family Curculionidae. 
In October 2014, we found an adult T. maculatus (362 mm SVL) near "Lazareto" neighborhood (22.4110, -83.7085; $45 \mathrm{~m}$ a.s.l.), Pinar del Río city, Pinar del Río Province. We found the snake at 1530 hours under a pile of tiles in an urban area. The stomach content revealed a partially digested anole (possibly A. sagrei), and fragments of an heteropteran (family Cydnidae), an unidentified spider, and fire ants (Wasmannia auropunctata).

Tropidophis maculatus is a slender snake of nocturnal habits. We have repeatedly observed this species foraging on vegetation at night. Despite the small sample size, anoles possibly represent a frequent prey item for T. maculatus. This snake probably captures its prey on their sleeping perches employing an active foraging mode. The arthropods found in the digestive tracts of some individuals might be part of the stomach contents of the lizard prey or might have been inadvertently swallowed. However, in one case we found a beetle as the only prey item. Nonetheless, chitinous remains might take longer to pass the digestive tract than the soft tissue and bones of any associated vertebrate prey item.

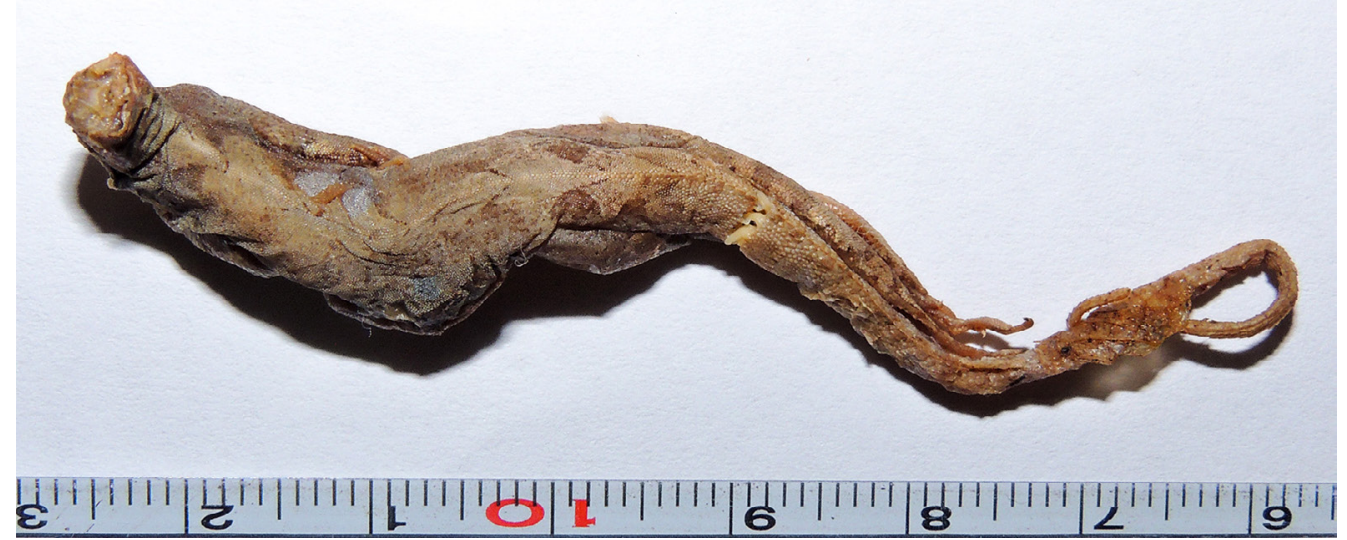

Figure 2. Partially digested male Cuban White-fanned Anole (Anolis homolechis) regurgitated by a Tropidophis maculatus (Fig. 1). Scale bar in millimeters. Photo by Ruben Marrero.

\section{Acknowledgments}

We thank Ruben Marrero for field assistance and photographs.

\section{References}

Collette BB (1961) Correlations between ecology and morphology in anoline lizards from Havana, Cuba and southern Florida. Bulletin of the Museum of Comparative Zoology, 125, 137-162.

Rodríguez Schettino L, Mancina CA, Rivalta González V (2013) Reptiles of Cuba: Checklist and geographic distribution. Smithsonian Herpetological Information Service, 144, 1-96.

Schwartz, A, Henderson RW (1991) Amphibians and Reptiles of the West Indies. Descriptions, Distributions, and Natural History (University of Florida Press, Gainesville). 